\title{
JMLE
}

The National Association for Media Literacy Education's

Journal of Media Literacy Education 11 (1), 97 - 113

https://doi.org/10.23860/JMLE-2019-11-1-5

\section{A Case for the Common Good: \\ How Training in Faith-based Media Literacy Helped Teachers Address Social Justice Issues in the Classroom}

\author{
Maria Rosalia Tenorio de Azevedo \\ Loyola Marymount University
}

\begin{abstract}
This case study reveals how a faith-based initiative offering structured teacher training in media literacy. The program is centered in Catholic Social Teaching, encouraging the use of critical media literacy in the classroom to aid the learning of social justice issues. The critical literacy of Paulo Freire serves as theoretical framework to help answer the research question: How has a teacher training program in faith-based media literacy influenced teachers' practice when addressing social justice issues in the classroom? This case study relates the accounts of a middle school teacher, a high school teacher, and a college professor, graduates of the program. Participants discuss how the training influenced their practice. The data collected brought to light the Media Mindfulness Method, MMM, which according to participants promoted character education, solidarity, student empowerment, and values. MMM also served as a media literacy teaching aid because this strategy for media literacy education facilitated the integration of media education into any given discipline.
\end{abstract}

Keywords: teacher training, media literacy, social justice, media mindfulness, Catholic social teaching, Paulo Freire

The advent of digital media in mobile devices has increased media consumption among children (Kaiser Family Foundation, 2010). Omnipresent media on-the-go contributes to the power of media to control the masses for the profit of those who own mass media corporations (Torres \& Mercado, 2006). The so-callded new media is an amalgam of different old media types: text, image, sound, and video converge and are presented in an interactive form. Advertising is also more sophisticated, marketers use data about the user's navigation habits to offer highly targeted and ever more compelling ads, often in times disguised as content (Guynn, 2012). Students who lack an understanding of the complexity of today's media landscape are in a sociopolitical disadvantage (Fuxa, 2012) and can be called the new illiterate. Literacy in the twenty-first century demands a working knowledge of how digital media is produced and how it propels dominant 
discourses in detriment of those who consume it without the technical knowledge and critical skills necessary for informed engagement. Media literacy education can serve as a tool to address this social justice issue (Considine \& Haley, 1992; Reutzel \& Cooter, 1992; Semali, 2000; and Sinatra, 1990), but in the United States formal teacher training in media literacy is still lacking (Inan \& Temur, 2012; Schmidt, 2012). This study looks at how - inspired by the social doctrine of the Church - a group of Catholic educators in the country are addressing the problem.

\section{Context}

The history of faith-based media literacy in North America speaks to the very root of the discipline in the region. Pioneer media literacy advocate, John Culkin, Ph.D. (1928-1993) was a Jesuit priest. Culkin, founder of the Center for Understanding Media in NYC, avidly promoted media literacy education in the early 1960's, a work that warranted him the title of founding father of media literacy in the United States (Moody, 2003; Hailer \& Pacatte, 2007).

Following in his footsteps, renowned media literacy scholar Sister Elizabeth Thoman founded the Center for Media and Values, in Los Angeles, California, in 1977 (Baker, 2013). Thoman also published the cutting-edge magazine Media \& Values, "a forum in which to discuss the social and cultural implications of new communication technology" (Iaquinto \& Keeler, 2012, p. 15). Twenty-one years later, in 1989, the Center for Media and Values was rebranded to Center for Media Literacy (CML), branching out from its former faith-based focus. CML is recognized as one of the most influential national organizations in the field (Martens, 2010).

In the 1980s, in Canada, another Jesuit priest, Father John Pungente, was recognized as the pioneer in the field of faith-based media literacy education. Father Pungente went on to preside the Canadian Association of Media Education Organizations. Today, in the U.S., the Saint Gabriel Media Literacy Institute (a pseudonym) is the most prominent initiative in faith-based media literacy (Baker, 2013).

This case study examines how a middle school teacher, a high-school teacher, and college professor implemented media literacy education into their practice following their formal training in the discipline at the Saint Gabriel Media Literacy Institute, a faith-based non-profit organization dedicated to promoting media literacy education. The Institute offers teacher certification programs recognized in two archdioceses and in 14 dioceses in the United States. The program is heavily informed by Catholic social teaching and encourages teachers to explore with their students the social justice implications of media production and consumption.

\section{Purpose}

Chiefly, this case study revealed how social justice is applied in media literacy education as participants use Catholic social teaching as framework to dismantle and produce media messages. Secondarily, this study offers a qualitative report on how an independent media literacy certification program is filling the gap in professional development alternatives for teachers seeking formal training in 
media literacy. In addition, this study contributes to the research on teachers' perspectives in regards to how training in media literacy has influenced their own practices. This study derives from a larger research program (Tenorio de Azevedo, 2015) that examines media literacy education.

Freire (1967) warned educators about the qualitative deficits in education as a hindrance to securing democracy. Freire envisioned a literacy directly connected to the democratization of culture. For Freire literacy is "an act of creation, capable of releasing other creative acts" (Freire, 1967, p. 66). Repealing classic hierarchical pedagogy that places the teacher as an authoritarian figure from whom all knowledge emanates, Freire defended a literacy that arises directly from the social context of the student. Denouncing "banking" education, Freire (1970) urged educators "not to offer 'salvation' in the form of content to be 'deposited," to students (Freire 1970,49). Instead Freire encouraged teachers to engage students in dialogue to help them discover their level of consciousness about themselves, and the world. Freire insisted that educators should not pontificate their own worldview to students, but to explore the students' worldview and their role in the world.

Freire also defended the engagement of students into critical interpretation of media messages, suggesting in-class discussions of articles from magazines and newspapers as problem-solving exercise meant to avoid "banking" education. "It seems essential to examine the content of the editorials of the press, concerning the same event. Why newspapers are manifested differently on the same fact?" (Freire, 1970, p. 58). Freire went on to describe how dismantling media messages was enlightening for his students. In the Freirean creative pedagogy not only the student becomes an active agent in the educational process, but the very methodology of learning is subjected to the student, no longer the teacher (Freire, 1979). Freire's $(1967 ; 1970 ; 1979)$ advocacy for the democratization of literacy guided this study as theoretical framework. His work provided standards that helped analyze to what extent the phenomenon studied promoted democratic literacy, which the researcher deemed essential in the teaching of social justice.

Using this perspective, the researcher specifically looked at how prevalent were the instances in which students were given the freedom to rethink their social condition and act upon it, meaningfully shaping in-classroom instruction. Therefore, the critical literacy of Freire served as theoretical framework to help explore the research question: How has a teacher training program in faith-based media literacy influenced teachers' practice when addressing social justice issues in the classroom?

\section{REVIEW OF THE LITERATURE}

Media literacy education requires skills that traditional literacy does not, because it entails more than reading and writing. Media literacy teaches the ability to interpret media messages, through "a basic knowledge of how messages are produced and distributed to media audiences" (Park 2012, p. 188). The advent of the ubiquitous digital media added a new layer of complexity to critical media literacy education, and scholars have called for a new literacy. "[New] media 
literacies include the traditional literacy that evolved with print culture as well as the newer forms of literacy within mass and digital media" (Jenkins, Clinton, Purushotma, Robison, \& Weigel 2006, p. 19). The new literacy that Jenkins et al. (2006) defended functions as an expansion of mass media literacies. New literacy therefore raises expectations for teachers and students' technology-use abilities in order to meaningfully engage and produce media messages.

Digital media use requires different types of literacy. A student's level of new literacy will shape their meaning-making process while consuming media in digital format. "Our experiences of the internet will be determined by how we master its core competencies, which are not merely operational or technical competencies but, rather complex performances of knowledge assembly, evaluation of information content, searching the internet, and navigating hypertext" (Knobel \& Lankshear 2011, p. 23). Therefore, access to new literacy is a social justice issue, because those who lack a working knowledge of the idiosyncrasies of the widespread digital media are in socioeconomic disadvantage. Educators cannot simply focus on how to integrate new technologies in the classroom, and how to ensure student access to technological devices. Instead there must be a focus on adapting curricula to accommodate the demands digital media imposes on literacy (Parker, 2010). Because of its interactive nature and nearly omnipresence, new media poses even greater persuasion power of ideological indoctrination than old media, hence teacher training in new literacy is more pressing now than ever before.

\section{Teacher Training in Media Literacy}

Media literacy scholars have called the universities to disseminate teacher training in media literacy (Damico, 2004; DeAbreu, 2008; Gainer, 2010; Hobbs et al., 2011; Inan \& Temur, 2012; Keller-Raber, 1995; Kellner \& Share, 2005; Kubey, 1998; Schmidt, 2012; Silverblatt, 2001). "A big challenge for media literacy in the U.S. is thus to enter into teacher training programs and departments of education" (Kellner \& Share, 2005, p. 15). Teachers who lack formal training in media feel unprepared to integrate media literacy into their practice (Schmidt, 2012). Media literacy should be applied at every grade level across disciplines (Morrell et al., 2013), but early childhood educators, grades K-6, lag behind (Hobbs, et al, 2011).

Institutions of higher education could promote the new literacy by addressing the gap in professional training in media literacy, there could be more continued professional development in media literacy (Schmidt, 2012), or media literacy master programs (Inan \& Temur, 2012). In additional, administrators in schools of education by and large are called to embrace media literacy (Hobbs, 2004). Without proper administrator support, teachers interested in integrating media literacy into their practice are generally forced to learn it on their own (Goodman, 2013; Hobbs, 2004). "Media literacy education depends on the courage and perseverance of individual teachers who are inspired and motivated by a wide range of different understandings about the role of the mass media and popular culture in society." (Hobbs 2004, p. 56). As a result, teachers who set out to adopt media literacy on their own often lack a holistic formation and wind up adopting only parts of the discipline, such as using only a certain media type or genre (Sellers-Clark, 2006). A well-rounded teacher formation in media literacy requires 
funding, planning, and time (Keller-Raber, 1995). Lack of necessary funding for media literacy training and research has hindered the growth of the field (Goodman, 2013). Oftentimes teachers who adopt media literacy take upon themselves the responsibility to equip students to dismantle and create media messages. "Teachers interested in critical media literacy must make efforts to create space in the curriculum for all students, regardless of academic track, to debate culture through collective analysis of media and creation of alternative representations" (Gainer, 2010 , p. 372). But they are highly discouraged from doing so when the larger school community does not support their initiatives. Worse, marginalizing media literacy efforts at schools force teachers to promote the discipline outside the school curriculum (Goodman, 2013).

Media literacy education in the United States is still generally the result of efforts from independent educators and small organizations (Gainer, 2010). The Saint Gabriel Media Literacy Institute, subject of this study is one such organization. Nonetheless, Cheung (2005) defended that as educators, "it is our job to make use of media education to prevent the further exploitation of children by the mass media" (Cheung 2005, 363). Meanwhile, most educators concerned with providing their students with new literacy skills are left alone to train themselves, prioritize content, acquire the tools, and make the time to instruct their pupils in visual literacy, applied semiotics, multimedia production, and the like, all of which extrapolate the word-centered educational system that is still standard in America today.

While wealthy students receive information from abundant sources, unfortunately, for many students from disadvantaged backgrounds the school and the media are their main source of information about public culture (Gale \& Densmore, 2000). Students from a disadvantaged socioeconomic background generally lack firsthand cultural experiences afforded by traveling and the arts, for instance, which are widely available to wealthy students. Therefore, because the poor depend so heavily on the media and on the school to learn about the world, equitable media literacy instruction to pupils is a social justice issue, which demands systemic training of educators.

\section{METHODS}

The qualitative method is the most appropriate when the study aims to answer a "how" question (Yin, 1993). A case study provides an in-depth account of the context in which a phenomenon occurs in the social world therefore it is used to answer the research question: How has a teacher training program in faith-based media literacy influenced teachers' practice when addressing social justice issues in the classroom?

Partcipants. Three participants who completed the Saint Gabriel Institute's Advanced Media Literacy Training Certification program were selected to exemplify how they deployed media literacy in their practice to address social justice issues in the classroom. Participants selected were a middle-school teacher, a high-school teacher, and a university professor. All participants identify themselves as Catholic and teach at private faith-based educational organizations. 
The researcher was granted permission to attend the program as a participantobserver. In addition, participants were interviewed at their workplace and in their homes.

Data Collection. As a participant-observer, I performed observations during the 60 hours of the training program. Thirty hours of audio data were recorded, nearly half of them were transcribed, including the most relevant segments of inclass instructions and semi-structured interviews. Field notes followed an observational protocol based in the theoretical framework of the study. The researcher also kept a journal where descriptive data and direct quotations were documented. Table 1 shows the types ofn quantity of data collected. Participants were interviewed in a three-part cycle, informed by data analysis and the collection of supportive documents, such as student-produced media messages, curriculum, syllabus, and lesson plans, among other artifacts. Guided follow up questions which were then developed to collect additional information from participants.

Table 1

Type of Data Collected and Analyzed

\begin{tabular}{ll}
\hline Data & Length \\
\hline Field observations & 60 hours \\
Field notes & 42 pages \\
Audio recordings & 30 hours \\
Journaling & 7 days \\
Documents & 16 items \\
\hline
\end{tabular}

Data Analysis. Inductive data analysis was applied in this study (Glaser \& Straus, 1967). Data collection and analysis were guided by preceding analysis as relevant patterns and topics, and later, codes and themes emerged (Trochim, 1989; Yin, 1994). Tesch's (1990) data coding model was adopted. The initial data analysis resulted in general patterns, and subsequent analysis yielded narrower topics. Then, codes were identified to organize themes by topic. Themes were classified into three types: major, unique, and leftovers. Each theme was ordered according to their importance. Continuing data analysis pointed to new themes, which were first examined separately, and subsequently within the larger context of the data. Using a funneling model, the same data was re-analyzed considering different perspectives, compared and contrasted until exhaustion (Creswell 2003; Tesch 1990; Y in 1994). Likewise, silences and repetitions informed data analysis. When data analysis no longer produced new significant themes, final conclusions were drawn. NVivo - a qualitative data analysis software - was used to facilitate data management.

\section{CURRICULUM OVERVIEW}

The Saint Gabriel Media Literacy Institute offers a 60-hour media literacy training program designed for teachers and educators. Classes are offered on 
Saturdays during a 12-week format, or in a seven-day intense format during Summers. The program is divided in 12 modules as described on Table 2.

Those who graduate receive an Advanced Certificate in Media Literacy recognized as a catechist specialization in all participating dioceses. Lectures are conducted by two religious women who are formally trained in media literacy in addition to guest-lectors who are experts in different disciplines such as, film, television production, and theology of mass communication. The program is subsidized for teachers through grants made available by private donors and diocesan gifts.

Table 2

Course Modules for Advanced Certificate in Media Literacy

Media literacy: key themes and core concepts

Character education and media literacy

Pop culture and advertising

Adult formation and media

Music and pop culture

History of cinema and analysis

Philosophy, ideology, and media

Web literacy

Globalization, Catholic Social Teaching and media literacy

Faith-based media literacy

Theology and spirituality of communication

New media and five ways to make a difference

Theory and praxis

Source: Saint Gabriel Media Literacy Institute handout, 2014

The training follows the media mindfulness strategy (Hailer, 1996) for media literacy education. media mindfulness offers a faith-based framework for media education (Hailer \& Paccate, 2007), an approach that educators at the Saint Gabriel Media Literacy Institute find particularly helpful for teachers without a prior training in media, as Sister Mary, the founding-director of the program explains:

There's a great hesitancy because teachers conflate knowing how to operate technology with understanding the various - the different mediums and how it all comes together. ... They also may come with a certain bias against media. If you ask them to try to understand how it all works, it can be overwhelming. So, what are you gonna do about it? Media Mindfulness shows teachers how to do something about it. They don't have to be silent. They can talk about what students watch and consume.

The media mindfulness strategy is centered on the ideal of the common good and it encourages students to, beyond looking at technical aspects of the media message, reflect on the values media message reinforce or downplay, and how they should respond in light of the common good. In-class discussions are guided by a 
Media Mindfulness chart, which offers a road map for dismantling media messages by exploring the students' own values. Figure 1 shows the Media Mindfulness inquiry strategy. Participants who went on to integrate media mindfulness in their practice reported finding the wheel a time-saving tool, since it is applicable to any media message being analyzed.

\section{MeDia \\ MINDFULNESS}

The following is a simple strategy for media awareness, called media mindfulness. Note that the strategy involves four questions that appear quite simple-but whose answers are sometimes (like life) complex.

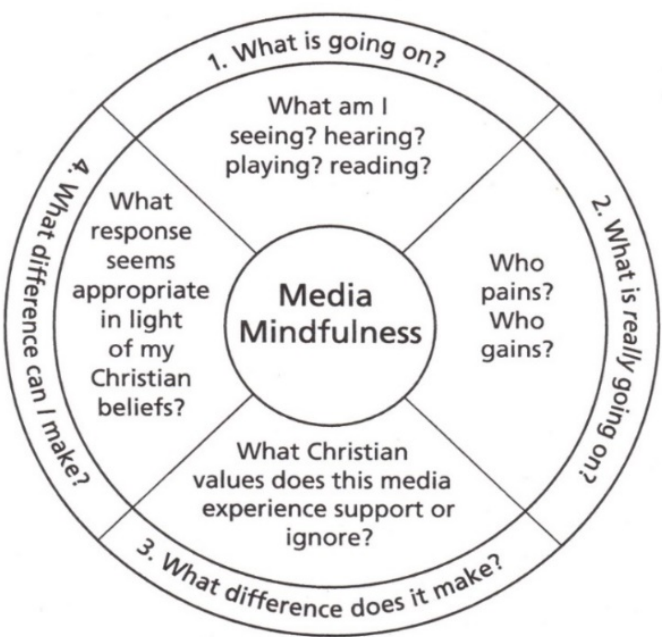

Figure 1

Media Mindfulness Wheel

Adapted from Media Mindfulness: Educating Teens about Faith and Media, 2007, by G. Hailer and R. Pacatte. Copyright 2007 by Saint Mary's Press. Used with permission.

\section{RESULTS}

In the data analysis for the larger research project, seventeen themes were identified yielding five categories: (1) rights and responsibilities; (2) preferential option for the poor and vulnerable; (3) dignity of work and rights of workers; (4) the common good; and (5) media mindfulness as an instructional strategy (Tenorio de Azevedo, 2015). In the results below, I explore how each of the three participants integrated media mindfulness into their instructional practice in relation to their understanding of its relevance to Catholic social teaching and the common good. 


\section{Integrating Media Mindfulness into Practice}

Elizabeth. Elizabeth holds a bachelor's degree in anthropology and a master's degree in religious studies, focused on the spirituality of media, from a renowned Catholic college. She taught social studies, history, and religion to the sixth, seventh, and eighth grades at a Catholic school. She pursued training in media literacy because, due to the pervasiveness of media, she wanted to equip her students with skills to discern how to responsibly consume and how to respond to media. Social issues are among the topics most discussed in Elizabeth's classes. In one in-class activity she addressed the issue of world hunger. Sixth, seventh, and eighth graders took part in exercises that highlighted the effects of hunger. In addition, they watched a documentary on the topic and were asked to reflect on how class divisions are evidentiated by hunger, the role that charity plays in solving the issue, and how they themselves can help the poor through media. "They are taught that as Catholic Christians it is their obligation to be of service to the world, and especially to the poor," Elizabeth commented.

She wanted her students to realize that they can help solve social challenges. She found media literacy helpful in addressing complex social issues like hunger, workers' rights, and the dignity of life with younger students: "I can't get into liberation theology, but I can talk a little bit about the rights of workers," Elizabeth explained. Media literacy has facilitated Catholic social teaching instruction, as she described:

The media literacy training definitely made me more aware that you need to use media in order to teach social justice. You can't just name the Catholic social teachings. You can't just give them a definition of what social justice is in the Catholic Church and expect it to resonate with them. If you give them an example of what social justice is within the media, then it's easier for them to understand it and go, "Oh, I get it."

Following her Media Mindfulness training, Elizabeth has tailored her lesson plans to integrate media literacy into her Catholic social teachings lessons. She said she made it a habit to ask herself "Is there a media component to this lesson?" as she goes through her planning. Elizabeth started making the Media Mindfulness wheel available to her students and used it to guide in-class discussions.

Paul. Paul was the theology teacher at a Catholic high school. He holds a bachelor's degree in science and another in psychology, in addition to graduate studies in theology. He underwent media literacy training at the Saint Gabriel Media Literacy Institute in 2006. His training made him reflect on how his students understood the media they consumed based on their own experiences and bias. He further became concerned about how media was influencing his students' perceptions of themselves and their world. He found that media literacy was particularly helpful to relay Catholic Social Teaching lessons, "There's this huge intersection between Catholic Social Teaching and the media." Paul commented. Paul asked his students to customarily analyze the media they consume: "They start looking at things that the Catholic Church considers rights and how the media portrays them as simply a matter of personal responsibilities and privileges." Paul 
encouraged his students to consider whether the media they consumed upheld or downplayed the values they themselves held. Paul brought social issues like access to clean water, immigration policies, workers' and women's rights to the forefront of media discussions with students, highlighting Catholic Social Teaching concepts of preference for the poor and vulnerable, and dignity of work and rights of workers. Paul explained:

Catholic social teaching is way bigger than the Church. We talk about the rights and responsibilities of human beings to one another: the social contract. Social justice issues are responsibilities we have human to human. These are human issues. Immigration is not a one-culture issue, neither is access to healthcare, or retirement. These are universal issues.

Media literacy helped Paul address polemic subjects with his students because the media messages served as a common ground to start a discussion. He noted, "When we are talking about healthcare, immigration reform, or about any of these social justice issues, we watch the news, and discuss it." He explained. Paul said that integrating media literacy and Catholic social teaching into his practice has helped him make his students aware of social issues within their own communities and how these issues moved the political debate.

Paul emphasized media production because he wanted his students to be as savvy producing videos as they were writing essays. He said, "When these kids go to college they are going to be asked to make videos. Ever more, it will not be uncommon for a professor to say 'Make me a film' because anyone can make a film in their camera-phones now. So why wouldn't I ask my kids?" Since the advent of camera-phones, Paul started asking his students to produce videos about the social issues addressed in class, and his students' creativity has continuingly surprised him. Paul usually allowed students to engage any media type or genre of their choosing. When possible, Paul pushed for combining media production with faith values, assigning projects like the production of media messages that describe the journeys of Saint Paul according to the Bible, or media messages that convey what it is like to be a Jew celebrating Hanukkah in the 21 st century.

"When I give my kids the license to be creative they do amazing stuff and often tell me the project was way more interesting than writing an essay," Paul concluded, adding that integration media literacy into his practice had been a winwin situation because it had allowed students to learn the formal theology curriculum while also mastering media literacy skills.

Dr. Agatha. Dr. Agatha is a tenured psychology professor at a private Christian university in the West Coast. She was drawn to the intersection of God and media. In her view, Catholic social teaching was a perspective for exploring media messages that dovetailed nicely with psychology, and she wanted her students to realize that media was worth examining. "As a professor, or as a teacher, we have to be versed in media, because our students are exposed to different forms of media," she explained. Dr. Agatha said video production skills are a must, noting, "When people say something that strike me, I pull out my camera-phone, and record them to use in class later. This is something I commonly do." Dr. Agatha 
said teachers can benefit from more training on multimedia production, including how to produce video projects with small budgets. In her experience, she said that it is common for professors to have an interest in mastering basic media tools to enhance their teaching. "We need those basic skills." She advocated and explained that her students already come to expect relevant media messages in her lectures, such as audio and video clips. "Part of the appeal of doing that is bringing in material that the students are very familiar with, then relating it to the context of the content I am teaching," she detailed.

Integrating media literacy into her practice when discussing social issues has improved classroom engagement, according to Dr. Agatha. Clips of news reports, documentaries, and even films have helped her increase empathy among her students for social issues they themselves have not faced. She said, "Students can read about individuals in the world who lack basic human rights and about governments who don't fulfill their responsibilities to individuals, but when students actually see, for example, a documentary, that brings the issue to life." In her social psychology class prejudice and stereotyping are topics that media literacy has helped her discuss with her students by surveying news reports about women around the world who lacked basic human rights. "My students themselves may not experience these forms of social injustice but, through discussion of media messages, I bring it to their attention that there are others who do experience social injustice and the role media plays in it." Dr. Agatha said,

Part of her university's mission is to strengthen service, purpose, and leadership in the lives of their students, which inspires Dr. Agatha to use the principles of Catholic social teaching. She said, "Catholic social teaching, although it has the name Catholic, has a broader teaching. It's more about social justice in general independent of being Catholic." Dr. Agatha applied principles of Catholic social teaching, such as the common good, when dismantling media messages in the classroom. She intentionally used mainstream news reports, because in her understanding the media source can set up barriers to receptivity, noting, "I purposely choose Time Magazine for my psych of women class, because students won't think I'm choosing a topic from some feminist magazine. I'm using mainstreaming media." She said her intent was to make sure her students were aware that the social issues addressed in class, such as gender-selective abortion, bride burning, and female genital mutilation, were actually taking place in the world today.

\section{The Common Good}

Media mindfulness is a strategy for teaching media literacy that is shaped by the interest in the moral implications of the media's influence in the social world in accordance to the responses of the media consumer, which may promote the common good. In sum, media mindfulness is media literacy education in the context of faith formation, informed by the Judeo-Christian tradition and chiefly concerned with promoting the common good. Media mindfulness invites a media analysis that goes beyond the scrutiny of how the message influences the media consumer, focusing instead on a broader scale of influence: how it influences different social groups. Further, Media mindfulness compels a common good 
informed response by the media consumer-i.e., students - to the messages they consume, encouraging the production of common good driven media messages as a way to respond.

Participant teachers pointed to the common good as the link between media literacy and Catholic social teaching. Following their media literacy training, teachers reported choosing media messages that allowed for the discussion of social issues and focusing media analysis around social justice topics like world hunger, access to clean water, and women's rights, resulting in students being more empathetic towards those suffering and more prompt to acting in solidarity to address such social justice issues as a way to respond to the media messages studied.

The most important discovery of this research was noting how the common good can link media literacy education to social justice issues, as teachers explored with students themes of Catholic social teaching in media analysis and media production. When teachers brought up the common good during media analysis discussions, students engaged in critically thinking about the role of media within the social world and were also eager to engage in solidarity. They were in essence propelled to became active agents of social change, as described by Freire (1967).

Participants reported that media mindfulness helped them to be consistent in promoting social responsibility via media literacy, because the Media Mindfulness wheel asks students to answer: "What difference can I make?" This simple question permits teachers to coax students to think beyond simply asking, "Why is this message being sent?" as proposed by Thoman (1997). The media mindfulness line of inquiry as prescribed by its wheel, encourages students to respond to media in a tangible way in order to make a difference in favor of the common good. Media mindfulness adds to the media literacy scholarship as it elicits emphasis on students' responses to the media message they consume, which go beyond producing their own media messages to serving as an active agent (Freire 1979) in the promotion of the common good.

While media mindfulness recommends that students learn how to produce their own media messages and do so as a way to respond to the media they consume, it also accepts different types of responses that the student may deem appropriate, from praying for those portrayed in the media, to volunteering in community service to help solve the social issue explored in-class, to engaging in political advocacy, or works of charity, for example. media mindfulness hence carries a callto-action. Not every student feels called to produce media-even although they should know how - and those who do produce media messages, will not produce media messages in response to every single media message they consume, other responses are appropriate. The emphasis is on being mindful of the role media plays in society at-large, and how one should respond personally. More often than not students will simply respond by writing a message to the media producer or the advertiser, or even respond by self-reflection of how the media message supports or challenges their own values, how it may influence different people in varying levels, and whether it is worth consuming. Participant teachers reported students often choosing to act in solidarity or political advocacy within their own communities. 
In conclusion, through media mindfulness students are educated to be mindful of all the media they consume and produce. Students are challenged to act upon their new acquired knowledge through the question: "What difference can I make?" The fullness of the data collected revealed that character education, solidarity, student empowerment, and values are promoted through the Media Mindfulness Model, as shown in Figure 2. It also revealed that the MMM served as a media literacy teaching aid because this strategy for media literacy education facilitated the integration of media education into any given discipline. Teachers note that their instructional practices changed as result of formal media literacy training. All participants reported integrating media literacy in their classroom instruction regularly since graduating from the Saint Gabriel Media Literacy Institute. They were also consistent in affirming that media mindfulness has proven especially helpful in addressing social justice issues in the classroom.

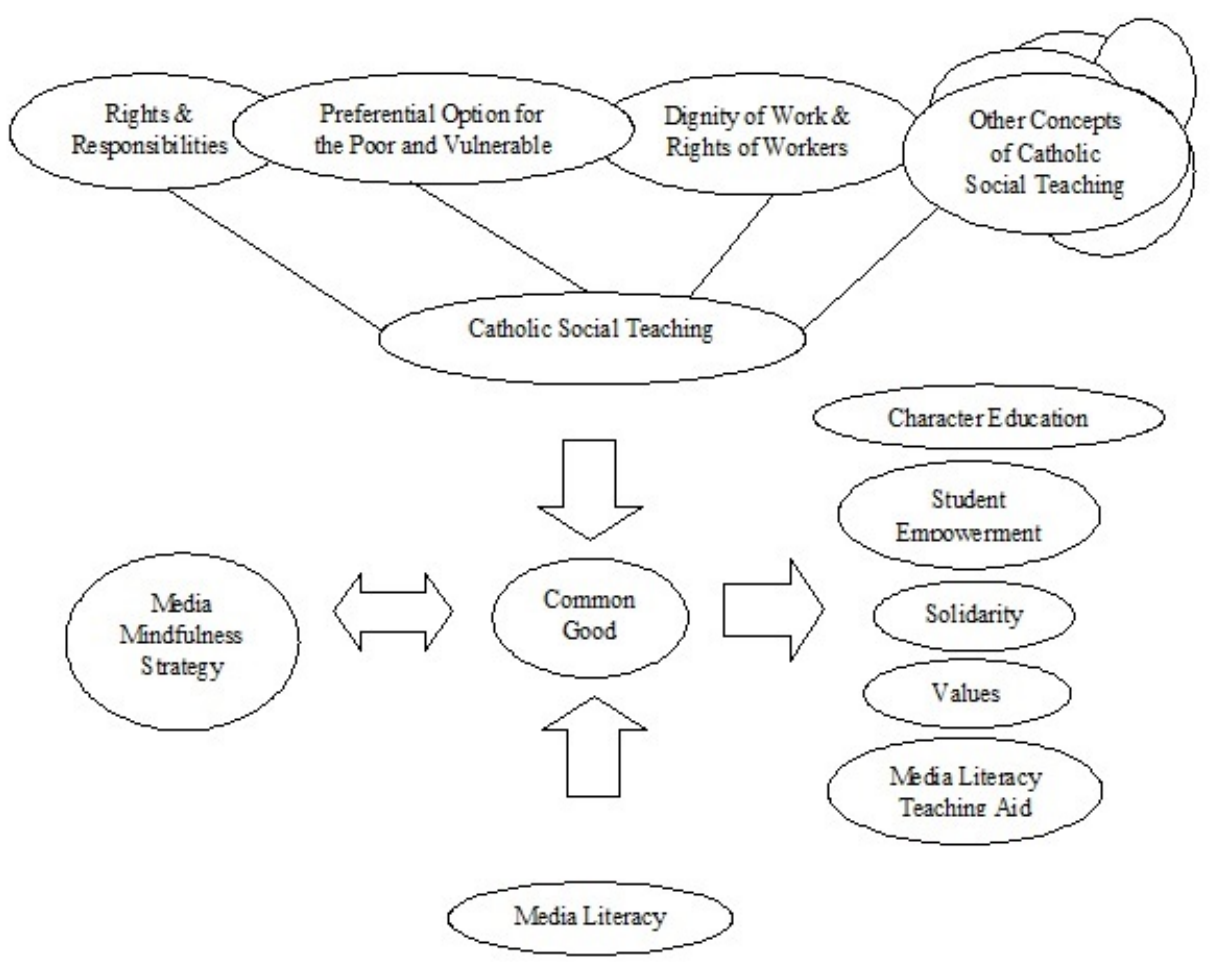

Figure 2

Media Mindfulness Model

Based on Juddeo-Christian values, Catholic social teaching refers to the body of intellectual work that calls the Church to examine and respond to social justice issues in light of the principles of "human dignity, the common good, solidarity, and subsidiary for all people, with particular attention to people who are poor and vulnerable" (Plitt, Belanger, \& Belanger, 2012, p. 124). These principles are meant to encourage and guide the faithful to address social justice issues like civil rights, peace, poverty, access to clean water, hunger, workers' rights, housing, child welfare, immigration, environmental conservation, among others 
(Compendium of the Social Doctrine of the Church, 2004). The essential guidelines of Catholic social teaching have been emphasized by Catholic bishops around the world because they provide instructions on how to respond to the social justice challenges faced around the world.

Media literacy supports the development of the common good, which is a major objective of Catholic social teaching. Respect for the fundamental rights of the person, acknowledging human society's spiritual and temporal prosperity, and making efforts to advance world peace are actions we take in pursuit of the common good. Media literacy education can enable the Church to uphold the dignity of human life and promote the stewardship of God's creation.

\section{REFERENCES}

Baker, Frank. 2013. A Timeline on the History of Media Literacy. http://www.frankwbaker.com/history of media literacy.htm

Cheung, Chi-Kim. 2005. "The Relevance of Media Education in Primary Schools in Hong Kong In the Age of New Media: A Case Study.” Educational Studies 31 4: 361374.

Considine, David M., and Gail E. Haley. 1992. Imagine that: Developing Critical Instruction.

Englewood: Teachers Ideas Press.

Creswell, John W. 2003. Research Design: Qualitative, Quantitative, and Mixed Methods Approaches 2nd ed. Thousand Oaks: Sage Publications.

Damico, Amy M. 2004. Exploring the Complexities of Personal Ideologies, Media Literacy Pedagogy and Media Literacy Practice. Doctoral diss., University of Massachusetts, Dissertations \& Theses: The Humanities and Social Sciences Collection (AAT3118291).।

DeAbreu, Belinha S. 2008. The Implementation of a Media Literacy Curriculum in thePublic Schools: Three Case Studies. Doctoral diss., University of Connecticut, 2008. Dissertations \& Theses: The Humanities and Social Sciences Collection (AAT3340451).

Freire, Paulo. 1967. Educação Como Prática da Liberdade. Rio de Janeiro: Paz e Terra.

. 1970. Pedagogia do Oprimido. Rio de Janeiro: Paz e Terra. 1979. Conscientização: Teoria e Prática da Libertação, uma Introdução ao Pensamento de Paulo Freire. São Paulo, Brazil: Cortez e Moraes.

Fuxa, Robin. 2012. "What Dirty Dancing Taught Me About Media Literacy Education." Journalof Media Literacy Education, 4 2:179-183.

Gainer, Jesse S. 2010. "Critical Media Literacy in Middle School: Exploring the Politics of Representation." Journal of Adolescent \& Adult Literacy 53 5: 364-373.

Gale, Trevor, and Kathleen Densmore. 2000. Just Schooling: Explorations in the Cultural Politics of Teaching. Buckingham: Open University Press.

Glaser, Barney, and Anselm Strauss. 1967. The Discovery of Grounded Theory: 
Strategies for Qualitative Research. Chicago: Aldine Publishing Company.

Goodman, Steven. 2013. Teaching Youth Media: A Critical Guide to Literacy, Video Production, and Social Change. New York: Teacher College Press.

Guynn, Jessica. "Google Merging User Data to Improve Experience, Help Advertisers." Los Angeles Times, 2012, January 24, accessed September 20, 2016: http://latimesblogs.latimes.com/technology/2012/01/googleplans-to-merge-more-user-data-across-its-products.html

Hailer, Gretchen. 1996. Believing in a Media Culture. Winona: Saint Mary’s Press.

Hailer, Gretchen, and Rose Pacatte. 2007. Media Mindfulness: Educating Teens about Faith and Media. Winona, MN: Saint Mary's Press.

Hobbs, Renee, Al-Humaidan, Rawia, Nuala Cabral, Aggie Ebrahimi, and Jiwon Yoon. (2011). "Field-Based Teacher Education in Elementary Media Literacy as a Means to Promote Global Understanding." Action in Teacher Education 33: 144-156.

Hobbs, Renee. 2004. "A Review of School-Based Initiatives in Media Literacy Education." American Behavioral Scientist. 48(1), 42-59.

Inan, Taskin, and Turan Temur. 2012. "Examining Media Literacy Levels of Prospective Teachers." International Electronic Journal of Elementary Education, 4(2), 269-285.

Iaquinto, Stephanie. \& Keeler, John. 2012. "Faith-based Media Literacy Education: A Look at the Past with an Eye Toward the Future." Journal of Media Literacy, 4(1), 12-31.

Jenkins, Henry, Katie Clinton, Ravi Purushotma, and Alice J. Robison. 2006. "Confronting the Challenges of Participatory Culture: Media Education for the 21st Century." The John D. and Catherine T. MacArthur Foundation. https://mitpress.mit.edu/sites/default/files/titles/free download/978026251 3623 Confronting the Challenges.pdf

Keller-Raber, Candace. 1995. Media Literacy Skills: Factors Influencing Successful Student Mastery. Doctoral diss., Florida State University. Dissertations \& Theses: The Humanities and Social Sciences Collection (AAT9540057)

Kellner, Douglas, and Jeff Share. 2005. "Toward Critical Media Literacy: Core Concepts, Debates, Organizations, and Policy." Discourse: Studies in the Cultural Politics of Education 26 3: 369-386.

Knobel, Michelle, and Colin Lankshear. 2011. New Literacies. New York: NY. Open University Press.

Kubey, Robert. 1998. "Obstacles to the Development of Media Education in the United States." Journal of Communication 48 1: 58-69.

Martens, Hans. 2010. "Evaluating Media Literacy Education: Concepts, Theories and Future Directions." Journal of Media Literacy Education, 2(1), 1-22

Moody, Kate. 2003. "John Culkin, The Man Who Invented Media Literacy: 19281993. " Center for Media Literacy. Retrieved from http://www.medialit.org/reading-room/john-culkins-man-who-invented- 
media-literacy-1928-1993

Morrell, Ernest, Rudy Dueñas, Veronica Garcia, and Jorge Lopez. 2013. Critical Media Pedagogy: Teaching for Achievement in City Schools. New York: Teachers College Press.

Park, Sora. 2012. "Dimensions of Digital Media Literacy and the Relationship with Social Exclusion." Media International Australia 14 2: 187-188.

Parker, Jessica K. 2010. Teaching Tech-Savvy Kids: Bring Digital Media into the Classroom, Grades 5-12. Thousand Oaks: Corwin.

Plitt, Linda., Belanger, David., \& Belanger, Kathleen. 2012. "Catholic Social Teaching:

Principles for the Service and Justice Dimensions of Social Work Practice and Education." Journal of the North American Association of Christians in Social Work, 39(2), 119-127.

Reutzel, Ray D., and Robert B. Cooter. 1992. Teaching Children to Read: From Basals to Books.

New York: Merril.

Schmidt, Hans C. 2012. "Essential but Problematic: Faculty Perceptions of Media Literacy Education at the University Level." Qualitative Research Reports in Communication 13 1: 10-20.

Sellers-Clark, Sharon E. 2006. Are Great Cities Institutions Preparing Pre-Service Teachers to Teach Media Literacy? A Comparative Study. PhD diss., Wayne State University, Dissertations \& Theses: The Humanities and Social Sciences Collection (AAT3232089).

Semali, Ladislaus. 2000. Literacy in Multimedia America: Integrating Media Education Across the Curriculum. New York: Falmer Press.

Silverblatt, Art. 2001. Media Literacy: Keys to Interpreting Media Messages, ed. 2.

Westport: Greenwood Publishing Group.

Sinatra, Richard. 1990. “Combining Visual Literacy, Text Understanding, and Writing for

Culturally Diverse Students. Journal of Reading 33 8: 612-617.

Rideout, Victoria J., Ulla G. Foehr, and Donald F. Roberts. 2010. "Generation M2: Media in the Lives of 8 to 18-Year-Olds." The Henry J Kaiser Family Foundation.

Tenorio de Azevedo, Maria R. 2015. Media Literacy and the Common Good: A Link to Catholic Social Teaching. Doctoral diss., Loyola Marymount University. LMU/LLS Theses and Dissertations. 191. https://digitalcommons.lmu.edu/etd/191

Tesch, Renata. 1990. Qualitative Research: Analysis Types and Software Tools. New York: Falmer.

Thoman, Elizabeth. 1997. Skills and Strategies for Media Education. Los Angeles: Center Media Literacy.

Torres, Myriam, and Maria Mercado. 2006. "The Need for Critical Media Literacy in Teacher Education Core Curricula." Educational Studies: Journal of the American Educational Studies Association 39 3: 260-282. 
Trochim, William M. K. 1989. "Outcome Pattern Matching and Program Theory." Evaluation And Program Planning 12 4: 355.

Yin, Robert. 1993. Applications of Case Study Research. Newbury Park: Sage Publishing.

1994. Case Study Research: Design and Methods 2nd ed. Thousand Oaks: Sage Publishing. 